A N N A L E S

UNIVERSITATIS MARIAE CURIE-SKŁODOWSKA

LUBLIN - POLONIA

VOL. XXXIII

SECTIO FF

2015

\title{
JAN ZDUNIK
}

Uniwersytet Warszawski

\section{Reportaż w stanie dekonstrukcji. O Życie $w$ dżungli Zbigniewa Uniłowskiego}

Deconstruction of reportage. About The Rye in the Jungle by Zbigniew Uniłowski

W znanym szkicu Tragiczność, drwina i realizm Kazimierz Wyka konstatuje, że wraz z przedwczesną śmiercią Zbigniewa Uniłowskiego w 1937 roku odchodzi jedyny prawdziwy realista okresu międzywojennego. Autor Wspólnego pokoju według Kazimierza Wyki - jako jedyny przebrnął przez niełaskawe dla realizmu czasy po I wojnie światowej, jednak tragiczna śmierć spowodowała, że młody prozaik „nie wypowiedział się naprawdę".

Świadomość niepowetowanej straty dla polskiej literatury mieli również zaproszeni przez „Wiadomości Literackie” pisarze i krytycy, którzy wypowiedzieli się o Uniłowskim w specjalnym numerze (co było rzadkością) wydanym przez czasopismo Mieczysława Grydzewskiego po śmierci pisarza. Czesław Miłosz uznał, że wraz ze śmiercią Uniłowskiego „zniknął jeden z największych talentów pisarskich młodego pokolenia”, Jan Parandowski wspominał o „drogich obietnicach talentu", które nie spełniły się przez przedwczesną śmierć artysty. W krytycznych epitafiach pojawiały się porównania do największych pisarzy światowych - Karola Dickensa, Louis-Ferdinanda Céline'a, Gustawa Flauberta. Dla Tadeusza Dołęgi-Mostowicza Uniłowski był konserwatystą, dla Władysława Broniewskiego wyznawał idee socjalistyczne, według Leona Pomirowskiego jego technika była naturalistyczna, według Wacława Kubackiego - realistyczna. Słowem: każdy interpretował twórczość Uniłowskiego na podstawie własnych

${ }^{1}$ Por. K. Wyka, Tragiczność, drwina i realizm, [w] idem, Pogranicze powieści, Warszawa 1974, s. 10, a także rozważania o nieistnieniu realizmu w polskiej rzeczywistości międzywojennej (s. 10-21). 
reguł krytycznych i wyciągał takie wnioski, by wykazać wybitność autora $̇ y t a ~ w$ $d \dot{z} u n g l i^{2}$. Oczywiście można tłumaczyć taki nastrój tekstów atmosferą żałoby po śmierci prozaika w dwudziestym ósmym roku życia. Zapewne specyficzny charakter tego czasu nie pozostał bez wpływu na ocenę dorobku pisarza. Trudno jednak thumaczyć tak afirmatywne podsumowanie twórczości Uniłowskiego wyłącznie epitafijnym modelem zamieszczonych w „Wiadomościach” analiz. Autorzy przywołanych literackich „nekrologów” zdawali sobie sprawę, jak się wydaje, ze skali talentu autora Dwudziestu lat życia. Nie ulega - jak sądzimy - wątpliwości, że literatura polska straciła w 1937 roku pisarza, który mógł stać się jednym z najwybitniejszych twórców dwudziestowiecznej prozy; błyskotliwą karierę przerwał przedwczesny zgon.

Co pozostało z dorobku Zbigniewa Uniłowskiego w siedemdziesiąt dziewięć lat po jego śmierci? Z pewnością Wspólny pokój, spopularyzowany także przez ekranizacje Jerzego Antczaka i Wojciecha Jerzego Hasa. Sam tekst, raczej nieinterpretowany dziś już przez pryzmat „powieści z kluczem”, pozostaje barwnym obrazem naturalistyczno-groteskowego (a może nawet makabreskowego) talentu pisarza. Niestety, wydaje się, że w powszechnej świadomości pozostaje Uniłowski autorem jednego dzieła, swojego debiutanckiego opus magnum.

Celem niniejszego artykułu będzie spojrzenie na twórczość ,jedynego realisty międzywojnia" przez pryzmat jego raczej zapomnianych już dzieł, czyli reportaży. Teksty te, choć wydane także po II wojnie światowej, są dzisiaj rzadko omawiane i interpretowane ${ }^{3}$. Pomijanie reporterskich utworów Uniłowskiego w namyśle krytycznym nad polską literaturą faktu okresu międzywojnia jest, jak się wydaje, dużym przeoczeniem, ponieważ reportaże autora Człowieka w oknie - Żyto $w$ dżungli oraz Pamiętnik morski - stanowią dowód na rosnącą samoświadomość tej formy pisarstwa dokumentalnego w dwudziestoleciu. Uniłowski doprowadził bowiem w swoich tekstach do dekonstrukcji modelu reportażu podróżniczego. Działanie to nie byłoby z pewnością możliwe, gdyby nie istniał powszechnie uznany model prozy niefikcjonalnej. W naszej analizie zajmiemy się dłuższym, bardziej znanym i bardziej udanym tekstem, czyli Żytem w dżungli; Pamiętnik morski bowiem zasadniczo replikuje schematy zastosowane przez autora Dwudziestu lat życia we wcześniejszym utworze.

${ }^{2}$ Por. „Wiadomości Literackie” 1937, nr 50, tam m.in: C. Miłosz, Zbigniew Uniłowski, J. Parandowski, Przemówienie nad grobem, T. Dołęga-Mostowicz, Kim był Zbigniew Uniłowski, W. Broniewski, Żegnaj, Zbyszku, I. Krzywicka, Polski Copperfield, L. Pomirowski, Uniłowski-naturalista, W. Kubacki, Realizm Uniłowskiego.

${ }^{3}$ Por. Z. Uniłowski, Żyto w dżungli. Pamiętnik morski. Reportaże, wybór i posłowie B. Faron, Kraków 1981. 


\section{PISARZ AUTOBIOGRAFICZNY}

Był Uniłowski z pewnością jedną z najbarwniejszych postaci dwudziestolecia międzywojennego. Użyć można wytartego, konwencjonalnego zwrotu: jego biografia z powodzeniem mogłaby służyć za materiał do ciekawego filmu. Przypomnijmy najważniejsze fakty: wychowany w biedzie w niecieszącej się dobrą sławą dzielnicy Warszawy - Powiślu, zostaje zauważony przez Karola Szymanowskiego, gdy pomiędzy kelnerską pracą w „Astorii” czyta powieści Conrada. Znajomość ze znanym kompozytorem pozwala mu na podjęcie pierwszych prób literackich. W „międzyczasie” początkujący prozaik poznaje Jarosława Iwaszkiewicza, gdy próbuje mu, jako akwizytor znanej firmy, sprzedać... maszynę do pisania. Po dołączeniu do kwadrygantów opisuje życie młodych poetów w słynnym Wspólnym pokoju, który prowokuje obyczajowy skandal, ale jednocześnie otwiera pisarzowi drogę do sławy. W 1934 roku, już jako autor skandalizującej powieści, dzięki pomocy wpływowego urzędnika Ministerstwa Spraw Zagranicznych wyjeżdża do Brazylii. Tam pisze właśnie swoje dwa najsłynniejsze reportaże. W „Wiadomościach Literackich” ukazuje się Dzień rekruta - antymilitarne opowiadanie, które spowodowało skandal, szczególnie w konserwatywnych kręgach, i zmusiło Uniłowskiego do powrotu do Polski. Gdy jego sytuacja materialna zdaje się stabilizować, pisarz bierze ślub, przeprowadza się do willowej dzielnicy, zostaje ojcem i umiera nagle w 1937 roku $^{4}$.

Przypomniane powyżej szczegóły biograficzne mogą wydać się niepotrzebne - współczesna teoria literatury już od wielu lat mówi o ,śmierci autora” i przestrzega przed próbami korzystania ze szczegółów z osobistego życia pisarza. Prawo to jednak, skądinąd zapewne słuszne przy interpretowaniu utworów fikcjonalnych, trudne jest do zastosowania w przypadku literatury faktu, gdzie zbieżność między realnym autorem a główną instancją nadawczą w utworze wydaje się jednym z głównych warunków istnienia gatunku. Przypadek Uniłowskiego jest, jak sądzimy, szczególny tym bardziej. Autor Dwudziestu lat życia miał powiedzieć: „nie mogę pisać to, czegom nie przeżył" ika pisał o nim Witold Gombrowicz: ,jedynym dostępnym Uniłowskiemu tematem jest sam Uniłowski i można by powiedzieć, że Uniłowski tylko na gruncie autentycznych przeżyć Uniłowskiego czuje się jak u siebie w domu"'. Według autora Pamiętnika z okresu dojrzewania bezkompromisowość drogi twórczej pisarza wynika w dużej mierze z osobistych doświadczeń i trudności materialnych

\footnotetext{
${ }^{4}$ Por. szczególnie: B. Faron, Zbigniew Uniłowski, Warszawa 1969, s. 12-27; J. Iwaszkiewicz, Książka moich wspomnień, Kraków 1968, s. 305-310.

${ }^{5}$ Cyt za: J. Ossowski, Uniłoszczak w Kwadrydze, „Poezja” 1979, nr 1-2, s. 33.

${ }^{6} \mathrm{~W}$. Gombrowicz, Uniłowski zaplatany w ludziach, [w:] idem, Proza (fragmenty). Reportaże, krytyka literacka: 1933-1939. Dzieła tom XII, pod red. J. Błońskiego, J. Jarzębskiego, wybór i układ J. Jarzębski, Kraków 1995, s. 324.
} 
i społecznych, które stawały na drodze jego kariery pisarskiej ${ }^{7}$ Pełna skandali biografia artysty zgodna jest ze stylem jego twórczości. Już w 1929 roku pisał Uniłowski w liście do Karola Szymanowskiego: „Mnie się zdaje, że gdy człowiek (młody zwłaszcza) ma w krótkim czasie umrzeć, to podczas choroby - dożywa intensywnie to, co miałby przeżyć do czasu śmierci, w normalnym czasie"8. Czy młody prozaik już wtedy przeczuwał przedwczesną śmierć? Oczywiście trudno to orzec, jednakże wydaje się, że w biografii Uniłowskiego, tak literackiej, jak i osobistej, wiele jest ze świadomości konieczności walki o pozycję we wrogim świecie. Stąd ostry ton w powieściach pisarza i liczne, bezpruderyjne czerpanie „z prawdziwego życia”, a wreszcie chęć przeżycia jak najwięcej, jak najbardziej intensywnie. Uniłowski w swoim krytycznym, skrajnym realizmie jest także głosem straconego pokolenia katastrofistów, które zwykło się zwać „pokoleniem 1910", debiutantów roku 1932, wzrastających ze świadomością ciemności zła i rodzącego się faszyzmu9. Jako kronikarz powojennego lost generation porównywany jest do działającego w podobnej po części sytuacji społecznej Tadeusza Borowskiego $^{10}$. Jak wspominała po latach Hanna Mortkowicz-Olczakowa, była w Uniłowskim „bezwzględna, okrutna chęć dowiedzenia się całej prawdy o ludziach i ich życiu" ${ }^{11}$. Ta chęć maniakalnego niekiedy weryzmu prowadziła często do powstania dzieł bezkompromisowych, dekonstruujących. Takimi tekstami są Żyto w dżungli oraz Pamiętnik morski.

Wskazówek interpretacyjnych w biografii Uniłowskiego szukano w przypadku analizowania właściwie wszystkich jego dzieł. Wspólny pokój był krytykowany za warstwę faktograficzno-plotkarską przez jednego z głównych przeciwników takich praktyk - Karola Irzykowskiego. Ze względu na łatwą identyfikację pierwowzorów powieść ukazała się w atmosferze skandalu ${ }^{12}$. Nie mniejsze dyskusje wywołał kolejny tekst pisarza, czyli antywojskowy i pacyfistyczny Dzień rekruta. Międzywojenna krytyka miała problem z odpowiednim zaszeregowaniem utworu. Wydrukowany w „Wiadomościach Literackich” w 1934 roku nie został oznaczony żadnym kwalifikatorem gatunkowym. Kwestia ta nie ułatwiała kryty-

\footnotetext{
${ }^{7}$ Ibidem, 323-324.
}

${ }^{8}$ List Zbigniewa Uniłowskiego do Karola Szymanowskiego z 22 listopada 1929 roku, cyt. za: B. Faron, Z korespondencji Z. Uniłowskiego, „Miesięcznik Literacki” 1968, z. 2, s. 109.

${ }^{9}$ Tak pisał o Uniłowskim we wspomnieniowym artykule Czesław Miłosz. Por. idem, Zbigniew Uniłowski, „Wiadomości Literackie...”, por. też. J. Pieszczachowicz, Niewolnicy pozorów (o Zbigniewie Uniłowskim w 25. rocznicę śmierci), „Tygodnik Powszechny” 1962, nr 47; J. Katz, Młody, gniewny Uniłowski, „Twórczość” 1963, nr 8.

${ }^{10}$ J. Katz, op. cit., s. 18-19, 29-30.

${ }^{11}$ H. Mortkowicz-Olczakowa, Zbigniew Uniłowski (portrety $i$ wspomnienia), „Życie Literackie" 1958 , nr 4, s. 8.

${ }^{12}$ B. Faron, Twórczość Zbigniewa Uniłowskiego w świetle międzywojennej krytyki literackiej, „Rocznik Naukowo-Dydaktyczny. Wyższa Szkoła Pedagogiczna w Krakowie” 1966, Prace Historycznoliterackie III, s. 114-115. 
kom zadania; część odbiorców doszła do wniosku, że tekst należy uznać za faktograficzny i reporterski ${ }^{13}$. Dlatego też szczególnie prorządowi recenzenci sądzili, że utwór Uniłowskiego ma charakter antypaństwowy; ze względu na pierwszoosobową pozycję narratora utożsamiano go z samym autorem ${ }^{14}$. Głos w dyskusji zabrał sam Mieczysław Grydzewski. Redaktor naczelny czasopisma wyjaśniał charakter tekstu i odpowiadał na zarzuty „Gazety Polskiej”:

Nie będziemy nawet przeciwstawiali poglądu czasopisma literackiego (tj. naszego) na utwór Uniłowskiego - poglądowi redakcji dziennika politycznego, która nie umiejąc rozróżnić rodzajów literackich, nazywa Dzień rekruta reportażem, aczkolwiek reportaż wymaga najściślejszej autentyczności zjawisk i faktów (w reportażu musi być zaznaczony czas i miejsce akcji, muszą występować rzeczywiści ludzie, o prawdziwych nazwiskach itd.), a sam fakt opowiadania w pierwszej osobie nie przesądza: nikt nie nazwie szesnastu tomów proustowskiego cyklu reportażem, chociaż narracja utrzymana jest od początku do końca w pierwszej osobie ${ }^{15}$.

Dyskusja, jaka rozgorzała w środowisku literackim po opublikowaniu opowiadania, doskonale pokazuje „w praktyce” trudności genologiczne, jakie miała krytyka dwudziestolecia z prozą niefikcjonalną. Dodajmy jeszcze, że w 2014 roku Dzień rekruta został wydrukowany w szeroko reklamowanej... antologii reportażu ${ }^{16}$.

Podobnie sprawa ma się w przypadku ostatniego utworu Uniłowskiego Dwadzieścia lat życia. Według przyjaciela pisarza, Stanisława Ryszarda Dobrowolskiego, autor po prostu potraktował swoją biografię jako interesujący materiał artystyczny ${ }^{17}$. Tym razem krytyka była bardziej przychylna pisarzaowi - pojawiły się nawet górnolotne porównania do Kraszewskiego oraz Prusa ${ }^{18}$. To krótkie z konieczności przypomnienie recepcji twórczości autora Pamiętnika morskiego pozwala jednak na przyjęcie opinii Kazimierza Czachowskiego, który nazwał prozaika „pisarzem autobiograficznym”, tworzącym w gruncie rzeczy poprzez literaturę swoją zamaskowaną biografię ${ }^{19}$.

${ }^{13}$ Ibidem, s. 121.

${ }^{14}$ Ibidem; B. Faron, Zbigniew Uniłowski, s. 40-43.

${ }^{15}$ (m.g.) [M. Grydzewski], Jeszcze „Dzień rekruta”, „Wiadomości Literackie” 1934, nr 50, s. 5; por. też idem, $O$ „Dzień rekruta”, „Wiadomości Literackie” 1934, nr 49. „Gazeta Polska” nazwała tekst Uniłowskiego paszkwilem i twierdziła, że jego przedstawienie wojska jest jednostronne; według redakcji przed publikacją Dnia rekruta „Wiadomości” winny zamieścić odpowiedni komentarz. Por. Fetyszyści, „Gazeta Polska” 1934, nr 338.

${ }^{16}$ Por. M. Szczygiel, Szczegót doprowadzony do manii, [w:] Antologia reportażu polskiego XX wieku, t.1, 1901-1965, pod red. idem, Wołowiec 2014, s. 352-354.

${ }^{17}$ S. R. Dobrowolski, O Zbigniewie Uniłowskim, „Ateneum” 1938, nr 2, s. 132.

${ }^{18}$ B. Faron, Twórczość Zbigniewa Uniłowskiego..., s. 127-128.

${ }^{19}$ K. Czachowski, Pisarz autobiograficzny, „Gazeta Polska” 1937, nr 274. Dokładnie recepcję Uniłowskiego w międzywojniu omawia B. Faron w cytowanym artykule i w swojej monografii pisarza (s. 27-66). 


\section{ŻYTO W DŻUNGLI - PRZECIW NIEPRZEDSTAWIENIU}

Emigracja międzywojenna - historia i literackie przedstawienia. Rekonesans.

Tradycja relacji z podróży sięga nawet czasów starożytnych ${ }^{20}$. W przypadku polskiej literatury reportażowej pojawiające się od oświecenia relacje z podróży pełnią tym ważniejszą funkcja, że w ich ramach kształtują się pierwsze typologie oraz reguły pisania faktograficznego (choć samo uprawianie podróży i podróżopisarstwo bywało bardzo krytykowane $)^{21}$. Jak wskazuje Czesław Niedzielski, to właśnie z licznych relacji z podróży wyłania się wpisany w istniejącą pozatekstową przestrzeń rzeczywisty podmiot, uwierzytelniający świat przedstawiony ${ }^{22}$. Zatem podróżopisarstwo z końca XVIII wieku będzie źródłem nie tylko współczesnego reportażu podróżniczego, ale stanowi także fenomen prekursorski wobec gatunku reportażu w ogóle.

Długoletni rozwój relacji z podróży sprawia, że w XX wieku reportaż podróżniczy wydaje się gatunkiem już ukształtowanym ${ }^{23}$. Nie ulega wątpliwości, że gdy Zbigniew Uniłowski wyjeżdża do Ameryki Południowej w 1934 roku, gatunek reportażu podróżniczego jest już stałą i znaną formą. Warto zastanowić się, jaki stosunek do jego formy wyraża w swoich tekstach podróżniczych.

W Stowniku rodzaju i gatunków literackich badacz zagadnienia, Jacek Maziarski, o reportażu bezpośrednio nie wspomina, zaznacza jednak, że to właśnie relacje z dalekich krain były pierwszymi, prereporterskimi gatunkami ${ }^{24}$. Również Maria Wojtak, autorka monografii o gatunkach prasowych, napomyka tylko o typie reportażu podróżniczego, nie różnicując go jednakże od pozostałych modeli tekstu reporterskiego ${ }^{25}$. Mariusz Szczygieł i Wojciech Tochman w niedawno wydanej Biblii dziennikarstwa ograniczają swój wywód wyłącznie do pragmatycznych rad dla młodych dziennikarzy, nie decydując się na prezentację specyfiki reportaży podróżniczych ${ }^{26}$.

${ }^{20}$ Por. M. Piechota, Jaka Ameryka? Polscy reportażyści dwudziestolecia międzywojennego o Stanach Zjednoczonych, Lublin 2002, s. 7-11.

${ }^{21}$ Por. C. Niedzielski, O teoretycznoliterackich tradycjach prozy dokumentarnej (podróż - powieść - reportaż), Torun 1966, s, 11-51.

22 Por. ibidem, s. 52-55.

${ }^{23}$ A. Rejter, Kształtowanie się gatunku reportażu podróżniczego w perspektywie stylistycznej i pragmatycznej, Katowice 2000, s. 8.

${ }^{24}$ J. Maziarski, Reportaż, [w:] Słownik rodzajów i gatunków literackich, pod red. A. Gazdy i S. Tynieckiej-Makowskiej, Kraków 2006, s. 634-635.

${ }^{25}$ M. Wojtak, Gatunki dziennikarskie, Lublin 2004, s. 270.

${ }^{26}$ M. Szczygieł, W. Tochman, Reportaż prasowy, [w:] Biblia dziennikarstwa, pod red. A. Skworza i A. Niziołka, Kraków 2010, s. 294-306. 
Typologie rozmaitych gatunków podróżniczych zarysowuje w swoim szkicu Bożena Witosz ${ }^{27}$. Według niej literackie relacje z podróży możemy uszeregować, biorąc pod uwagę kilka aspektów: konstrukcję narratora, modele podróżnika, aktywność podmiotu, projektowanego czytelnika, relacje nadawczo-odbiorcze, komponenty sytuacyjne, profilowaną rzeczywistość, styl i wreszcie aksjologię 28 . Reportaż podróżniczy - w odróżnieniu od przewodnika - wymaga bezpośredniej, subiektywnej tekstowej obecności podmiotu, zakłada - w przeciwieństwie do np. listu z podróży - przedstawienie kilku różnych punktów widzenia, realizuje model aktywnego podmiotu i jest otwarty na aksjologiczną perspektywę prezentacji świata ${ }^{29}$. Mimo oczywistych różnic między poszczególnymi podgatunkami podróżniczymi cechą ich wszystkich jest spełnianie przede wszystkim funkcji poznawczej - pokazanie nieznanego czytelnikom otoczenia.

Cechą dystynktywną reportażu jest przemieszczenie reportera do obcej przestrzeni i zdanie z niej relacji odbiorcy - zrealizowanie wymienionej przed chwilą funkcji poznawczej. Pamiętać jednak trzeba, że przestrzeń, do której udaje się Uniłowski-reporter, jest znacząca także z politycznego punktu widzenia. Brazylia stanowiła bowiem ważny punkt na symbolicznej mapie Polski w dwudziestoleciu międzywojennym.

Charakterystyczną cechą państwowości polskiej po 1918 były problemy gospodarcze wynikające z niedoskonałości gospodarczej, słabego rozwoju technologicznego czy różnic między terenami trzech zaborów. Skutkiem niekorzystnych zmian sytuacji społeczno-ekonomicznej II Rzeczypospolitej było istnienie ludzi „zbędnych”, czyli takich, którzy mogli wyemigrować z kraju bez większej szkody dla gospodarki. Tacy obywatele, a także ci z mieszkańców kraju, którzy chcieli wyjechać w celu polepszania jakości życia, stanowili tzw. potencjał emigracyjny. Samych „ludzi zbędnych” było szacunkowo od 2,4 do nawet 8,8 miliona $^{30}$. Krótko mówiąc, nowe państwo było przeludnione i nie mogło zapewnić wszystkim obywatelom odpowiedniego standardu życia. Cechą charakterystyczną emigracji dwudziestolecia międzywojennego stało się jej organizowanie przez państwo ${ }^{31}$. Politykę II Rzeczypospolitej należy uznać za zdecydowanie proemigracyjną. Administracja państwowa starała się organizować wyjazdy z kraju poprzez ustanowienie prawa wolności migracji, opiekę nad emigrantami, podpisywanie umów z państwami docelowymi migracji czy wreszcie narodowościową „kontrolę” procesu (emigracja była również uznawana za narzędzie rozluźnienia etnicznych

${ }^{27}$ B. Witosz, Gatunki podróżnicze w typologicznym ujęciu genologii lingwistycznej, [w:] Wokót reportażu podróżniczego, t. 2, pod red. D. Rotta, Katowice 2007.

${ }^{28}$ Ibidem, s. 19-29.

${ }^{29}$ Por. ibidem.

${ }^{30}$ H. Janowska, Emigracja zarobkowa z Polski 1918-1939, Warszawa 1981, s. 69-82.

${ }^{31} \mathrm{~J}$. Mazurek, Kraj a emigracja. Ruch ludowy wobec wychodźstwa polskiego do krajów Ameryki Łacińskiej (do 1939 roku), Warszawa 2006, s. 148. 
napięć w państwie) ${ }^{32}$. Planowano również - choć w większości przypadków te projekty były jedynie mrzonkami - kolonizację niektórych terenów ${ }^{33}$. Mimo tak prowadzonej polityki zanotowano spadek emigracji. Jak podaje E. Kołodziej, w międzywojniu wyemigrowało około miliona osób, a w latach 1871-1939 aż 3,5 miliona $^{34}$. Oczywiście, w ten sposób nie udało się wykorzystać całego potencjału emigracyjnego Polski. $Z$ różnych względów (kryzys ekonomiczny, mniej przyjazna polityka państw docelowych, reemigracje) mobilność obywateli Rzeczypospolitej była mniejsza niż w czasach zaborów. W przypadku interesującej nas Brazylii główny ruch emigracyjny miał miejsce w pierwszej połowie ostatniego dziesięciolecia XIX wieku i na początku XX wieku ${ }^{35}$. Ocenia się, że w tych latach mogło z Polski do Brazylii wyemigrować nawet ponad 100 tysięcy obywateli, zaś w latach międzywojnia - zapewne tylko około 40 tysięcy $^{36}$.

Nie ulega wątpliwości, że cel literatury przedstawiającej emigrację międzywojenną był nie tylko artystyczny, lecz także propagandowy. Wobec przedstawionej powyżej polityki emigracyjnej prozatorskie prezentacje życia na uchodźstwie stanowiły również materiał agitacyjny. Być może właśnie takiego tekstu wymagał od Uniłowskiego jego protektor, Wiktor Drymmer, jeden z wpływowych polityków Ministerstwa Spraw Zagranicznych, pracujący też nad kolonizacyjnymi projektami Polski ${ }^{37}$. Powrót Uniłowskiego do Polski nie był oczywiście spowodowany niespełnieniem wymagań Drymmera (zresztą jego teksty zostały opublikowane już po powrocie z Ameryki), lecz opublikowaniem w „Wiadomościach Literackich" Dnia rekruta. Trudno jednak zaprzeczyć, że Żyto w dżungli nie mogło być użyte w celach politycznych - obraz emigracji przedstawiony w reportażu daleki jest od idealizacji.

Wiele podróżniczych reportaży międzywojennych utrzymywało mityczne przekonanie o misji kolonizacyjnej Polski i zachęcało do emigracji. Podobnie było w przypadku reportaży brazylijskich. Przede wszystkim dominował w nich raczej opis kolorytu wspaniałej przyrody niż przedstawienie życia emigrantów. Po drugie, mimo elementów negatywnej prezentacji życia diaspory w Ameryce

\footnotetext{
${ }^{32}$ Por. J. Plewko, Sprostać migracji. Pomoc migrantom ekonomicznym z ziem polskich (połowa XIX-początek XXI wieku), Lublin 2010, s. 90-10, H. Janowska, op. cit., s. 99-153.

${ }^{33}$ Por. E. Kołodziej, Wychodźstwo zarobkowe z Polski 1918-1939, Warszawa 1982, s. 192199, 236-252.

${ }^{34}$ Ibidem, s. 253.

${ }^{35}$ Por. K. Groniowski, Polska emigracja zarobkowa w Brazylii 1871-1814, Wrocław 1972, s. $31-168$.

${ }^{36}$ Por. J. Mazurek, op. cit., s. 61-62, H. Janowska, op. cit., s. 157, 165, 222; E. Kołodziej, op. cit., s. 93-95, 160, 174-175, 211-217. Mechanizmy emigracyjne w dwudziestoleciu omawiają w szeroki sposób cytowane pozycje Plewko, Janowskiej i Kołodzieja.

${ }^{37}$ Por. E. Kołodziej, op. cit., s. 238. Por. też: W. Drymmer, Zadania Ministerstwa Spraw Zagranicznych $w$ dziedzinie emigracji, b.m., 1935; idem, Wspomnienia, „Zeszyty Historyczne” 1973, z. 29; oraz ibidem, 1974, z. 30.
} 
Południowej, zasadniczo teksty gloryfikowały polskiego chłopa, zaznaczały jego pracowitość i wyższość cywilizacyjną nad autochtonami, w ten sposób utwierdzając przekonanie o mocarstwowej sile II Rzeczypospolitej ${ }^{38}$. Na popularność literatury podróżniczej wskazuje reakcja krytyki. W „Roczniku Literackim” na rok 1936 pisał Konrad Górski:

Nie wiem, czy ludzie mają więcej pieniędzy na podróżowanie, czy też są odważniejsi w spisywaniu swych wrażeń podróżniczych, ale to jedno jest pewne, że tak bogatego dorobku literatury podróżniczej, jak w 1936 roku, poprzednie lata nie wykazały ${ }^{39}$.

Rok wcześniej oceniał w tym samym wydawnictwie Kazimierz Wyka: „Referent literatury podróżniczej jest tego roku optymistą, zarówno jeśli idzie o ilościowy, jak o jakościowy plon jego działu” ${ }^{40}$. Recenzent „Prosto z Mostu” zauważał modę na reportaże i koniunkturalizm autorów egzotycznych relacji: „Panuje obecnie moda na książki podróżnicze, moda i koniunktura. Nowości sypią się jak z rogu obfitości. Rzecz oczywista, że wśród tej masy nowości wiele jest książek zbędnych i wręcz szkodliwych"41. Jesionowski dostrzegał także niedoskonałości reportaży, np. formalne niezorganizowanie, nieporządek czy koniunkturalną tematykę - zwiedzanie osad polskich kolonizatorów. Zasadniczo jednakże reportaże podróżnicze były oceniane dobrze - w podsumowaniach literatury lat międzywojennych z drugiego dziesięciolecia (1932-1937) tylko w 1932 uznał recenzent, że twórczość podróżnicza nie jest wysokiej jakości. W pozostałych przypadkach oceny były pozytywne. Oczekiwania czytelnicze dobrze podsumowuje opinia Górskiego o najlepszej według niego książce podróżniczej z 1935 roku, Ryby śpiewaja w Ukajali. Arkady Fiedler skupił się w książce przede wszystkim na przedstawieniu egzotycznej przyrody. Jak pisze recenzent:

Najpiękniejszą jednak książką podróżniczą z ubiegłego roku jest Arkadego Fiedlera Ryby śpiewają w Ukajali. [...] Tym razem opowiedział podróż w górę Amazonki, a potem największego jej dopływu, rzeki Ukajali. Znakomita galeria typów ludzkich, zwięzłe a wyraziste odmalowanie stosunków politycznych i gospodarczych w zakątkach tak straszliwie odległych od cywilizowanego świata, to są niejako wartości marginesowe książki Fiedlera. Głównym jej bohaterem jest puszcza dorzecza Amazonki, kraina pełna nieprawdopodobnych cudów przyrody i zarazem potwornej grozy ${ }^{42}$.

Książka Fiedlera doskonale odpowiada czytelniczemu zapotrzebowaniu na opis wyjątkowego krajobrazu brazylijskiego. Wielokrotne replikowanie tego

${ }^{38}$ Por. P. Frankowski, Emigracja polska w Brazylii w reportażu dwudziestolecia międzywojennego, [w:] Reportaż w dwudziestoleciu międzywojennym, pod red. K. Stępnika i M. Piechoty, Lublin 2004, s. 255-262; por. też B. Faron, Zbigniew Uniłowski, s. 182-189.

${ }^{39}$ K. Górski, Literatura podróżnicza, „Rocznik Literacki” 1936, s. 171.

${ }^{40}$ K. Wyka, Literatura podróżnicza, ,Rocznik Literacki” 1935, s. 216.

${ }^{41}$ A. Jesionowski, Kilka nowości podróżniczych, „Prosto z Mostu” 1937, nr 14, s. 7.

${ }^{42}$ K. Górski, op. cit., s. 205. 
wzorca - narracji zdominowanej przez zachwyt nad egzotyczną przyrodą - sprawiło być może, jak zauważa Bolesław Faron, że relacje z wypraw są do siebie niekiedy łudząco podobne:

$\mathrm{Na}$ uwagę zasługuje powtarzający się we wszystkich rozpatrywanych tu relacjach z podróży do Brazylii optymistyczny ton, nastrój radości i zadowolenia z kontaktów z tropikalnym klimatem, egzotyczną przyrodą i dostatnią egzystencją emigrantów. Ujęcia są tak nieraz łudząco do siebie podobne, że wykluczające na pierwszy rzut oka możliwość jakiejkolwiek weryfikacji czy zakwestionowania ${ }^{43}$.

Zatem w większości reportaży z Ameryki Południowej kontynent przedstawiony jest przede wszystkim jako interesujące zjawisko przyrodnicze, przyjazne również przyszłym mieszkańcom. Teksty te zachęcają zatem do wyjazdu z kraju i osiedlenia się na gościnnej ziemi od Parany do Rio de Janeiro.

Swoje podejście do reportażowości przedstawia Uniłowski w artykule Narkotyk Ameryki Poludniowej, opublikowanym przed prezentacją pozostałych, właściwych relacji z Brazylii ${ }^{44}$. Tekst ten stanowi specyficzny wstęp do reportaży prozaika. Autor Wspólnego pokoju opisuje w nim dwa typy dziennikarzy:

pisarz, przejmujący wrażenie natychmiast, chwytający je - że tak powiem - na migawkę i pisarz doznający początkowo oszołomienia i chaosu, lecz który w miarę obcowania wśród zjawisk mających stanowić w przyszłości treść jego pracy, odczuwa wyraźnie zarysowujące się i fundamentalne kontury interesujących go obiektów ${ }^{45}$.

Według Uniłowskiego pierwsza grupa to właśnie ,spece od reportażu”, drudzy „cierpiętnicy”, którzy muszą długo pracować nad krystalizowaniem formy utworu. W przeciwieństwie do reporterów mających łatwość obserwacji świata „długodystansowcy” mogą dać obraz psychologii i zwyczajów człowieka. Za „długodystansowca” uznawał się sam Uniłowski ${ }^{46}$. Kończy swój artykuł oryginalnym „credo” reportera: „Polowania na tygrysy, znojne przedzierania się przez puszcze dziewicze, płazy jadowite i cały bukiet niebezpieczeństw pozostawiam kolegom z pierwszej grupy. Ja w Ameryce widziałem przede wszystkim człowieka" ${ }^{47}$.

\footnotetext{
${ }^{43}$ B. Faron, Zbigniew Uniłowski, s. 186.

${ }^{44}$ Pierwodruk: „Wiadomości Literackie” 1935, nr 32.

${ }^{45}$ Z. Uniłowski, Narkotyk Ameryki Poludniowej, [w:] idem, Żyto w dżungli, s. 356.

${ }^{46}$ Ibidem.

${ }^{47}$ Ibidem, s. 356-357.
} 


\section{DESTRUKCJA REPORTAŻU}

W dość niekonwencjonalny sposób rozpoczyna Uniłowski relację z Brazylii. Notuje na samym początku podróży: „Prócz tępego zdenerwowania i oszołomienia przeżywam ordynarny niepokój. Nie ma we mnie nic z młodzieńca rozgrzanego żądzą przygód. Trudno, muszę się ująć w garść i poznać wnętrze Brazylii, skoro już tutaj jestem"48. Czy Uniłowski wziął się w garść? Tak twierdził recenzent „Wiadomości Literackich”, Stanisław Rogoż, który ciepło przyjął reportaż autora Wspólnego pokoju, uznając, że jest oryginalną próbą wobec wielu podobnych ujęć Brazylii ${ }^{49}$. Trudno jednak zgodzić się z entuzjastyczną oceną krytyka, gdy dokonamy analizy wypowiedzi reportera o samym sobie. Zacytujmy tylko kilka fragmentów:

Widać muszę, skoro jadę. Lecz żaden ze mnie dzielny podróżnik. Histeryczna, warszawska, kawiarniana wywłoka (ŻD: 42); Dziwiłem się sobie, jak wobec wielu ludzi napotkanych w mej podróży zachowywałem się oschle lub niegrzecznie. (A taki miły chłopiec był w Warszawie!). Prawie czułem się naładowany złem, czułem w sobie jady, w głowie czad; słowem niechęć do wszystkiego (ŻD: 99); Marne jest moje życie tutejsze - myślałem; ale biorę szkołę, nie ma co gadać. Myślałem jeszcze gorzej, w myśli tłukły mi się paskudne wyrazy (ŻD: 165).

Cytaty dotyczące psychiki bohatera oczywiście można mnożyć - zajmują, co dla reportażu dość wyjątkowe, dużą część tekstu. To już pierwsze, na razie tylko ilościowe, przekroczenie gatunku reportażu - dochodzi do przebudowy rządzących narracją faktograficzną proporcji. Celem tekstu dziennikarskiego jest bowiem, co podkreślano już w tej pracy, przede wszystkim zaprezentowanie obcego terytorium. Czytelniczy horyzont oczekiwań zamyka się zasadniczo w chęci poznania innej przestrzeni czy też prawdy o świecie ${ }^{50}$. Uniłowski bohaterem tekstu czyni głównie samego siebie ${ }^{51}$. Na tę specyficzną cechę Żyta zwracali uwagę już przedwojenni odbiorcy powieści (najczęściej jednakże mniej entuzjastyczni niż cytowany recenzent „Wiadomości Literackich”). Pisał Marian Piechal: „Tej podróży [po Brazylii - uzup. J. Z.] we właściwym sensie widzimy bardzo mało"52. Jerzy Andrzejewski oceniał: „W Życie w dżungli [Uniłowski - uzup. J. Z.] dużo mówi o sobie, wiele miejsca poświęca własnym nastrojom, wypowiada osobiste

${ }^{48}$ Z. Uniłowski, Żyto $w$ dżungli, [w:] idem, Żyto w dżungli. Pamiętnik morski. Reportaże, wybór i posłowie B. Faron, Kraków 1981, s. 9. Cytuję według tego wydania, używając skrótu ŻD; cyfra oznacza numer strony.

${ }^{49}$ Por. S. Rogoż, Żyto w dżungli, „Wiadomości Literackie” 1937, nr 43.

${ }^{50}$ Por. A. Mikołajczuk, Pragmatyczno-stylistyczne perspektywy analizy reportażu, „Poradnik Językowy" 2009, nr 10, s. 55-56.

${ }^{51}$ Por. B. Nowacka, Reportaże podróżnicze Z. Uniłowskiego - dylematy i paradoksy, [w:] Reportaż $w$ dwudziestoleciu międzywojennym, s. 151.

${ }^{52}$ M. Piechal, Żyto w dżungli, „Pion” 1936, nr 50, s. 5. 
poglądy”53. „Odnosi się niekiedy wrażenie, że cała rzeczywistość brazylijskiego interioru służy tu właściwie tylko za pretekst i oprawę dekoracyjną dla interesujących studiów i szkiców o psychologicznym przede wszystkim podkładzie" - to Bogdan Dudziński w „Robotniku” ${ }^{4}$.

Krótko mówiąc, reporter-Uniłowski korzysta właściwie wyłącznie z jednego punktu widzenia czy, jak można również powiedzieć, ze swojej fokalizacji. Charakterystyczne zaś dla reportażu jest korzystanie z rozmaitych subnarracji - źródeł, ekspertów, a przede wszystkim rozmówców ${ }^{55}$. Autor Dnia rekruta korzysta oczywiście z wiedzy i informacji uzyskanych od mieszkańców stanu Parana, lecz dominującą perspektywą staje się ta, która zostaje wytworzona przez jego mentalność. Słusznie zauważa monografista pisarza, że Uniłowski nie nazywa swojego tekstu reportażem, a pamiętnikiem, co pozwala na bardziej subiektywne i indywidualne opisywanie świata ${ }^{56}$. Sam prozaik deklarował: „Jeśli będę opisywał, to tylko swoje wrażenia i rzeczą czytelnika jest mi wierzyć lub nie" (ŻD: 108).

Tyle, jeśli chodzi o „ilościowe” studium tekstu Uniłowskiego, któremu bliżej do swoistego „reportażu psychiki”, katalogu bodźców, odczuć i refleksji niż do syntetycznej i dokładnej prezentacji świata zewnętrznego. Pisarz skupia się na oddaniu własnych, subiektywnych wrażeń z pobytu w Brazylii.

Są to wrażenia, jak na mający zachęcić czytelnika reportaż, dość wyjątkowe. Narrator tekstu, perceptor fascynującej, południowoamerykańskiej puszczy, obnosi się bowiem często ze swoim znudzeniem egzotycznym światem. W reakcji na obserwacje nieznanej przestrzeni zanotuje:

Cicho tu jest, trochę smętnie i dziko, drzewiny jakieś pokraczne, gdzieniegdzie trochę trawy, parę chałup, mała drewniana cerkiew na wzgórzu, w pyle kapliczka polska, gdzieniegdzie pokazują się światełka, czerń nocy przyprósza to wszystko, opada i na duszę, nudzi ach! jak nudzi (ŻD: 60).

Refleksja ta (tak naprawdę niezbyt głęboka) jest charakterystyczna dla całego Żyta $w$ dżungli. W innym miejscu narzeka podróżnik:

Doszedłem do pesymistycznego przeświadczenia, że wszystko to jest diablo nieciekawe, oprócz nieznanej mi dotychczas bliżej postaci polskiego chłopa - kolonisty, w której na podstawie luźnych obserwacji dopatrywałem się sensu i rzetelnej prostoty. Czekałem też okazji trwalszego zetknięcia się z tymi ludźmi, aby poświęcić im maksimum uwagi. Jasno sobie

${ }^{53}$ J. Andrzejewski, Sprawa do rozważenia, ,Prosto z Mostu” 1936, nr 45, s. 2.

${ }^{54}$ B. Dudziński, Wśród książek, „Robotnik” 1936, nr 324, s. 2.

${ }^{55}$ Por. A. Mikołajczuk, Punkt(y) widzenia w reportażu. Od etymologii nazwy do tworzywa gatunku, [w:] Punkt widzenia w tekście i w dyskursie, pod red. J. Bartmińskiego, S. NiebrzegowskiejBartmińskiej, R. Nycza, Lublin 2004, s. 113-126.

${ }^{56}$ B. Faron, Zbigniew Uniłowski, s. 188-189. Na temat reportażowych utworów Zbigniewa Uniłowskiego zob. także: idem, O twórczości reportażowej Zbigniewa Uniłowskiego, „Ruch Literacki” 1966, z. 5, s. 229-239. 
uświadomiłem, że nie jestem urodzonym podróżnikiem i że ta wędrówka od chałupy do chałupy razi mnie nudną pospolitością. Uroda natury brazylijskiej razi mnie swym przesadzonym bogactwem i rozwydrzeniem barw, jak razić może niegustownie ubrana żona właściciela dwudziestu jatek mięsnych w jakimś mieście. Brakowało tu pejzażu, który by wzruszył połączeniem drzew, łąki i rzeki, ową delikatnością i umiarem barw, nastrojów, jaka cechuje sielskie widoki europejskie. Roślinność tutejsza, upojona chamskim dobrobytem, kłębiła się w tłocznym rozpasaniu, drzewo wrastało w drzewo, mchy, trzciny i paprocie do spółki z lianami nachalnie tłoczyły się wokół drzew, tworząc jeden wielki skołtuniony matecznik. Słyszałem zachwyty o zachodach słońca. Dotychczas jeszcze ani razu nie widziałem solidnego widoku na ten temat. [...] Tutaj doświadczyłem, że natura może nudzić (ŻD: 81-82).

Czytając Uniłowskiego, trudno nie oprzeć się zwiększającemu się poczuciu nudy autora, lecz także niestety czytelnika. Przyroda brazylijska wydaje się reporterowi nużąca, nieciekawa, monotonna. Nazwie ją także „parszywą”, niebezpieczną, zagrażającą życiu, lecz na pewno nie fascynującą. Zawiedzeni musieli być odbiorcy reportażu, oczekujący niesamowitych, barwnych opisów dalekiej egzotyki. Otrzymali tylko nużące, jednostronne oceny jednostajnej flory Brazylii. Trudno zresztą było spodziewać się niesamowitych wrażeń z podróży, jeśli autorowi tajemnicze puszcze kojarzą się z senną atmosferą ,jesiennego Lubartowa”, jak podkreśli w pewnym momencie reporter. Nie sposób nie odnieść wrażenia, że eksponowanie znudzenia światem zewnętrznym ma charakter po części prowokacyjny. Jest to całkowite zaprzeczenie kanonów i konwencji reportażu podróżniczego, skupiającego się na pięknie egzotycznego otoczenia, zachęcającego do przyjazdu ${ }^{57}$. Czytelnik Uniłowskiego ma po lekturze tekstu poczucie uderzającej jednostajności klimatu brazylijskiego. Ironiczni recenzenci twierdzili, że pisarz był w czasie wyjazdu (by zacytować jego samego) ,wywłoką warszawską”, która nie mogła przyzwyczaić się do trudnych, reporterskich warunków i poległa w trakcie pracy reporterskiej ${ }^{58}$. Witold Gombrowicz sugerował, że Uniłowski ujawnił własną nudę, gdyż obawiał się, że w klasycznej formule reportażu okaże się gorszy od mistrzów gatunku - Fiedlera czy Janty-Połczyńskiego ${ }^{59}$. Warto zauważyć, że podobną metodę - co najmniej w jednej warstwie tekstu - wykorzystał sam Gombrowicz w Diariuszu Rio Parana, gdzie wielokrotnie podkreślał monotonię długiego oraz nużącego rejsu ${ }^{60}$.

${ }^{57}$ Por. Z. Ziątek, Proza - literatura doświadczeń społeczno-kulturalnych ,„ludzi nowych”, [w:] Literatura polska 1918-1975, t. 2, red. A. Brodzka, Warszawa 1993, s. 818.

${ }^{58}$ Por. np. A. Mikułowski, Cuduś w dżungli, „Myśl Narodowa” 1936, nr 50; Z. Kucharski, Chybiona ksiązka o Paranie, „Tygodnik Ilustrowany” 1937, nr 2.

${ }^{59}$ W. Gombrowicz, op. cit., s. 324.

${ }^{60}$ Por. W. Gombrowicz, Diariusz Rio Parana, [w:] idem, Dziennik 1953-1956, red. J. Błoński, Kraków 1986, s. 312-321; por. też: J. Pawłowski, Gombrowicz i lęk. Uwagi o „Diariuszu Rio Parana”, „Pamiętnik Literacki” 1977, z. 4, M. P. Markowski, Potworna powszedniość, [w:] idem, Czarny nurt. Gombrowicz, świat, literatura, Kraków 2004, s. 73-79. Zauważmy, że, podobnie jak w Pamiętniku morskim, monotonia doprowadza podróżnika do początków szaleństwa (por. J. Pawłowski, op. cit.). 
Abstrahując jednakże od celów takiego postępowania artystycznego, przyznać trzeba, że Uniłowski jest po prostu niezbyt zdolnym reporterem. Jeśli bowiem Uniłowskiego w Ameryce interesował ,przede wszystkim człowiek”, to być może właśnie opisy polskiego chłopa - jedynej pozytywnej postaci książki - są bardziej wartościowe niż obrazy fauny brazylijskiej. Niestety i tutaj czytelnik może czuć się zawiedziony. Najczęściej bowiem relacje z osad kolonizatorów nie wykraczają poza znane slogany, chwalące polskie wychodźstwo chłopskie, często realizujące $\mathrm{w}$ gruncie rzeczy mit Polaka-kolonisty-Piasta ${ }^{61}$. Ideałem Uniłowskiego-reportera jest pracujący na roli chłop, karczujący puszcze, walczący z ziemią.

Ci polscy chłopi z całym swym urokiem surowości i tężyzny, na tle dzikiej głuszy, przy ognisku, z twardą, poczciwą mową i szczerymi, nie golonymi twarzami wywierali na mnie uczucie serdecznej braterskości, pobudzali pogodę ducha, czuło się bliskość swoich, rodactwo. Nie było tu nudnych, parszywych rozmów dotyczących jakichś mętnych spekulacji w imię fałszywie pojmowanej pracy społecznej; wszystkich tych załganych i wzniosłych tematów: „Macierzy!”, „Religijności”, „Braterstwa!”, całej tej mętnej i nieudolnej propagandy w celu zachowania polskości kolonisty, który tę polskość czuje mocno i po swojemu i podświadomie obrusza się, kiedy wmawiają mu różni karierowicze emigracyjni to, co czuje we krwi, i zgrubiałymi rękami ustanawiając sobie byt na obczyźnie, pogardza w głębi duszy tymi wszystkimi „działaczami” i „prezesami”, dybiącymi na stłamszenie nabytej z takim trudem indywidualności i swobody. [...] To był człowiek wiadomy, prosty jak bochen razowego chleba, jak pracowicie wydarty tej twardej ziemi łan zboża. Przy tym ognisku zacząłem wyczuwać sens pięknej, życiowej misji polskiego chłopa-kolonisty w Brazylii (ŻD: 197).

Oczywiście, przeciwieństwem prostoty chłopa-emigranta jest działacz społeczny, propagandzista. Emigracyjni politycy dbają wyłącznie o własny interes, tworzą zwalczające się układy i koterie, nie pomagając tak naprawdę ciężko pracującym chłopom. Wszelcy działacze na obczyźnie są właściwie zaprzeczeniem prawdziwego osadnictwa ${ }^{62}$. Podobne opinie wygłasza Uniłowski o księżach, którzy nie zajmują się pracą duszpasterską tylko polityką - we fragmentach tych staje się książka antyklerykalna ${ }^{63}$. Najlepszym modelem propagandzisty jest bez wątpienia Grzeszczeszyn, wyimaginowany towarzysz podróży reportera.

Nie ulega wątpliwości, że dychotomiczne przedstawianie rzeczywistości, wychwalające pracę rolników i potępiające wszelką działalność społeczno-polityczną również jest uproszczeniem prezentacji świata. W miejsce jednego mitu - lansowanego przez środowiska państwowe, kreowany jest inny, niejako antysystemowy. Rozłożenie akcentów w opisie Brazylii, uderzające w promowanych przez państwo działaczy emigracyjnych, było ze strony prozaika również swego rodzaju wystąpieniem politycznym.

${ }^{61}$ Por. B. Nowacka, op. cit., s. 151-152, M. Piechal, op. cit.

${ }^{62}$ Por. J. Bajdor, Nie mogę pisać tego, czegom nie przeżyt... Unitowski po 30 latach, „Odra” 1967, nr 12, s. 29.

${ }^{63}$ Por. B. Faron, Zbigniew Uniłowski, s. 197-199. 
Podsumujmy więc: pierwsze przekroczenie gatunku reporterskiego stanowiło samo skupienie się na ego reportera, podkreślanie wyłącznie jednego punktu widzenia, prowokacyjny wręcz subiektywizm. Przypomnijmy tylko, że w tradycyjnych koncepcjach prozy reportażowej jej celem ma być maksymalne zobiektywizowanie przekazu, dokonujące się poprzez swoiste „ukrycie” perspektywy narratora - reportera. Drugim wyjściem poza konwencję tekstu faktograficznego było permanentne zaznaczanie nudy podróży, rzadko spotykane w reportażach z egzotycznych krain.

Nowoczesne podróżopisarstwo, szczególnie jeśli jest nudne, stanowi nie tyle drogę do poznania obcego świata, ile sposób odkrycia samego siebie ${ }^{64}$. Wydaje się, że taką funkcję pełni cała podróż do Brazylii. Aby móc dokonać analizy „wyprawy w głąb siebie" narratora warto na początku zastanowić się nad architekturą instancji nadawczych w tekście. Po pierwsze: Grzeszczeszyn, tajemnicza postać, którą autor określa wyłącznie jako wytwór swojej wyobraźni, pewne uogólnienie spotykanych na terenach emigracyjnych działaczy. Bez wątpienia słusznie zauważa Zygmunt Ziątek, że Grzeszczeszyn staje się stałym komentatorem, odmienną perspektywą świata, odmienną od tej prezentowanej przez narratora reportażu ${ }^{65}$. Towarzysz reportera wyraża stereotypowe ujęcia polskiej emigracji - nieświadomej, nienowoczesnej, wymagającej opieki ze strony działaczy i narodowego kleru. Wypowiedź rzutkiego działacza wydaje się inspirowana stylem gombrowiczowskim:

I dlatego ja jeżdżę po tych licznych skupiskach naszego chłopstwa i radzę, do porządku nawołuję, krew i pot z siebie wypuszczam, żeby sługi bożego słuchali, bo religia jest od wieków i będzie, bo ciemnota musi się czegoś trzymać. Oto misja moja, którą sam sobie narzuciłem i nie spocznę, dopóki jej nie spełnię (ŻD: 60-61).

Oczywiście, takie podejście zostaje wielokrotnie skompromitowane w trakcie podróży - zdawałoby się obyty z koloniami propagandzista okazuje się nierzadko ignorantem, nieznającym realiów naturalnych i społecznych życia w interiorze. Również jego wygląd zewnętrzny sprawia, że pozornie doświadczonego działacza można traktować tylko z pobłażaniem:

Ma on krótkie nogi - iksy, szerokie biodra, od nich tułów krzywo, bardziej na prawą stronę, szyja cienka z karczkiem chłystka, na tej cienkiej szyi głowa wielka, odstające uszy. To wszystko jest niechlujnie ubrane, koślawe buciory, sztylpy z grubej skóry, zeschłe, popękane potem trochę spodni khaki i marynarka czarna, wizytowa, z wąskimi rękawami, bardzo poplamiona (ŻD: 16-17).

${ }^{64}$ A. Czyżak, Nuda podróżowania, [w:] Nuda w kulturze, red. P. Czapliński, P. Śliwiński, Poznań 1999, s. 219.

${ }^{65}$ Z. Ziątek, op. cit., s. 821. 
Być może wprowadzenie Grzeszczeszyna ma charakter przede wszystkim retoryczny i ułatwia prowadzenie narracji, gdyż pozwala na uniknięcie nieeleganckich w reportażu monologów wewnętrznych ${ }^{66}$. Trudno oczywiście wykluczyć taką możliwość, wszak podobne wykorzystanie formy dialogowej ma długą tradycję w literaturze. Jednakże wydaje się, że ważniejszy od ewentualnej roli formalnej jest związek między postacią Grzeszczeszyna a osobą narratora. Już przed wojną Stanisław Furmanik, jeden z pierwszych recenzentów Żyta, sugerował, że towarzysz podróży Uniłowskiego jest odbiciem jego rzeczywistych poglądów na kwestie wychodźstwa brazylijskiego ${ }^{67}$. Zygmunt Ziątek podtrzymuje ustalenie Furmanika i konstatuje, że Grzeszczeszyn jest tak naprawdę inteligencką (albo raczej ćwierćinteligencką) częścią osobowości samego Uniłowskiego i stanowi wydzieloną, odmienną, nieakceptowaną perspektywę percepcji rzeczywistości ${ }^{68}$. Zatem konstrukcja narratora zostaje rozdzielona na dwie części - subosobowości. Staje się niepewna, nieciągła, niejasna. Takie działanie demistyfikuje pewność poznania nawet wewnątrz jednostki - nie możemy być pewni własnego postrzegania rzeczywistości, które rozbite jest na nieharmonijne elementy. Warto również zwrócić uwagę na samą formalną konstrukcję postaci Grzeszczeszyna, który stanowi oryginalne połączenie cech działacza emigracyjnego. Pogardliwie traktuje tak osadników, jak emigrantów; sam uważa się za dziejowego posłannika, który ma zadanie oświecać nieporadnych osadników:

\begin{abstract}
Bo... uważa pan... ja jestem społecznik, ja... mnie gryzie troska o dobro tego wychodźstwa, żeby ci ludzie nie zmarnieli, żeby im od czasu do czasu coś powiedzieć, poradzić, a i też przejechać po nich, jak źle żyją. Pan sobie czasem patrzy i myśli: o, ten Grzeszczeszyn to prostak! Nic dziwnego, młody pan, wychowany w mieście i w dobrobycie pewnie, dopiero pan w piórka obrastasz, a ja stary wyga kolonizacyjny, ja mam - nie chwaląc się panie, ale mam, no, mam od Boga ten talent rozumienia mas chłopskich, ja umiem do nich pogadać, chwycić ich za serce. Bo już temu się poświęciłem, bo jestem tym cichym, nieznanym bohaterem społecznym, tym pionierem wychodźstwa polskiego, co błądzi, idzie na manowce, od misjonarza stroni; a kimże jest misjonarz, jak nie tym łącznikiem ludzi z Bogiem, tym klejem, co ich trzyma, aby nie zmarnieli (ŻD: 66).
\end{abstract}

Przypomnijmy, że w podobny sposób tworzył bohaterów swoich reportaży Melchior Wańkowicz. Staje się w takim ujęciu Uniłowski prekursorem „mozaikowej konstrukcji" reportażu.

Charakter metapoznawczy pełnią również wielokrotnie przywoływane przez narratora uwagi o własnej psychice. Jan Aleksander Król pisał w tym kontekście o „oparze dostojewszczyzny” unoszącym się nad narracją reportażu, co ozna-

\footnotetext{
${ }^{66}$ Por. W. Szymański, Legenda o Uniłowskim, [w:] idem, Ballady przed burza. Szkoce literackie, Warszawa 1961, s. 118.

${ }^{67}$ Por. S. Furmanik, Żyto w dżungli, „Gazeta Polska” 1936, nr 341.

${ }^{68}$ Z. Ziątek, op. cit., s. 819-821.
} 
cza problemy psychologiczne oraz epistemologiczną niepewność w nieznanym świecie $^{69}$. Wiele bowiem z uwag narratora świadczy o wewnętrznych zmianach, dokonujących się w trakcie podróży:

Dziwnym porządkiem tutejszych stanów psychologicznych stan ten wydał mi się daleki i bez znaczenia (ŻD: 115); Myślałem jeszcze gorzej, w myśli tłukły mi się paskudne wyrazy (ŻD: 165); Tylko w Brazylii przystosowałem się zupełnie do klimatu umysłowego i ograniczyłem znacznie pracę swego umysłu (ŻD: 129).

Wydaje się, że wtrącenia takie mają dwojaki charakter. Po pierwsze, podkreślają stan umysłu bohatera, uniemożliwiający mu pewne poznanie świata. Po drugie, zwracają uwagę na subiektywizm percepcji rzeczywistości, zależnej od uwarunkowań mentalnych postrzegającego. Taka konstrukcja podmiotu mówiącego sprawia, że nie możemy ufać narratorskiemu obrazowi świata, gdyż ta rzeczywistość może stanowić wyłącznie wytwór owładniętej trudnościami psychiki bohatera.

Zastosowane przez Uniłowskiego zabiegi (stworzenie postaci Grzeszczeszyna, zaznaczanie trudności epistemologicznych) stanowią swego rodzaju manifesty ,antyreportażowe”. Wywodzący się bowiem z realizmu i naturalizmu reportaż pragnął (przynajmniej w początkowych fazach rozwoju) przedstawić rzeczywistość możliwie jak najbardziej obiektywnie, niejako bez udziału ukrytego narratora-reportera. Silnie podkreślając indywidualizm oraz niepewność swojej obserwacji świata przedstawionego, dokonywał jednocześnie Uniłowski dekonstrukcji ukrytych założeń prozy faktograficznej.

Współczesne poznanie określa francuski filozof Jean Baudrillard jako ,precesje symullakrów”; stan, w którym zaciera się różnica między znakiem a przedstawieniem, reprezentacją, znaczącym i znaczonym, reprezentowanym i reprezentującym. Jak pisze Baudrillard:

Przedstawienie wychodzi od zasady ekwiwalencji znaku i rzeczywistości (nawet jeśli ta ekwiwalencja jest utopijna, jest to założenie podstawowe). Symulacja natomiast wychodzi od utopii zasady ekwiwalencji, wychodzi od radykalnej negacji znaku jako wartości, wychodzi od znaku odzyskującego pełnię praw po śmierci wszelkich referencji. Podczas gdy przedstawienie dąży do wchłonięcia symulacji uznawanej za przedstawienie fałszywe, symulacja traktuje cały gmach przedstawienia jako jedno wielkie simulacrum ${ }^{70}$.

${ }^{69}$ Por. J. A. Król, Przemiany reportażu podróżniczego, „Orka na Ugorze” 1936, nr 28, s. 9.

${ }^{70}$ J. Baudillard, Precesja symulakrów, [w:] Postmodernizm. Antologia przekładów, pod red. R. Nycza, Kraków 1997, s. 180-181. 
Zatem we współczesnym świecie dochodzi do zatarcia podstawowej, poznawczej reguły, konstytuującej percepcję człowieka. Zanegowanie dychotomii świata i jego przedstawienia sprawia, że niemożliwe staje się oddzielenie jednego od drugiego - żadna reprezentacja nie ma siły referencjalnej, gdyż nie ma już samej referencji. Przedstawienie staje się światem, świat staje się przedstawieniem ${ }^{71}$.

Rodzajem politycznej symulacji było kreowanie mitycznego obrazu Polskikolonizatora, kraju mocnego i znaczącego na arenie międzynarodowej, co za tym idzie - idealizowanie terenów pod przyszłe panowanie i osadnictwo. Brazylia Lepeckich, Słonimskiego, Fiedlera była wielkim symullakrum, aktem założycielskim wszechogarniającej, symulacyjnej reprezentacji. Reprezentacja, zwielokrotniona $\mathrm{w}$ wielu propagandowych realizacjach, miała stać się prawdą, zespolić się ze swoim referentem.

Uniłowski dokonuje dyskwalifikacji takich przedstawień nie tylko przez prowokacyjne pisanie o nudzie podróży, lecz także przez podkreślenie roli silnego podmiotu jako medium poznającego i przekazującego fakty o świecie. W ten sposób obnaża konwencję reportażu, pozornie obiektywnego, realistycznego, naturalistycznie jeszcze scjentycznego ${ }^{72}$. Jest to jednocześnie destrukcja symulacji, która rości sobie prawo do prawdziwości i autentyzmu. Demistyfikująca działalność Uniłowskiego, pokazującego fałszywość takich „medialnych” konstrukcji świata, sprawia, że jego reportaż staje się ,antyreporterski”, a jego postawa jest podobna do podejścia innego „,antymedialnego” dziennikarza - Ryszarda Kapuścińskiego. Obaj twórcy próbują wyjść poza powszechne w masowym dziennikarstwie metody opisu świata, kreującego kolejne symullakry. Zarówno Kapuściński, jak i Uniłowski starają się zrobić to przez mocną konstrukcję poznającego podmiotu, organizującego rzeczywistość i walczącego z symulacją ${ }^{73}$.

\section{BIBLIOGRAFIA PODMIOTOWA}

Uniłowski Z., Żyto w dżungli, [w:] idem, Żyto w ḋ̇ungli, Pamiętnik morski, reportaże, wybór i posłowie B. Faron, Kraków 1981.

\section{BIBLIOGRAFIA PRZEDMIOTOWA}

Andrzejewski J., Sprawa do rozważenia, „Prosto z Mostu” 1936, nr 45.

Bajdor J., Nie moge pisać tego, czegom nie przeżył... Uniłowski po 30 latach, „Odra” 1967, nr 12.

${ }^{71}$ Por. ibidem.

${ }^{72}$ Por. M. Płachecki, Klucz do Uniłowskiego, „Tygodnik Kulturalny” 1972, nr 43, s. 4.

${ }^{73}$ Por. Z. Bauer, Antymedialny reportaż Ryszarda Kapuścińskiego, Warszawa 2001, s. 11-45. W swoim studium twórczości Kapuścińskiego Bauer również odwołuje się do Baudillardowskiej koncepcji symullakrum. 
Baudillard J., Precesja symulakrów, [w:] Postmodernizm. Antologia przektadów, pod red. R. Nycza, Kraków 1997.

Bauer Z., Antymedialny reportaż Ryszarda Kapuścińskiego, Warszawa 2001.

Chociłowski J., Żyto w dżungli, „Kontynenty” 1982, nr 1.

Czachowski K., Pisarz autobiograficzny, „Gazeta Polska” 1937, nr 274.

Czyżak A., Nuda podróżowania, [w:] Nuda w kulturze, red. P. Czapliński, P. Śliwiński, Poznań 1999.

Dobrowolski S. R., O Zbigniewie Uniłowskim, „Ateneum” 1938, nr 2.

Drymmer W., Wspomnienia, ,Zeszyty Historyczne” 1973-1974, z. 29-30.

Drymmer W., Zadania Ministerstwa Spraw Zagranicznych w dziedzinie emigracji, b. m., 1935.

Dudziński B., Nowe książki, „Naprzód” 1937, nr 175.

Faron B., Dzieje niezwykłej przyjaźni. Nieznane listy Zbigniewa Uniłowskiego do Karola Szymanowskiego, „Przekrój” 1978, nr 1739.

Faron B., O twórczości reportażowej Zbigniewa Uniłowskiego, „Ruch Literacki” 1966, z. 5.

Faron B., Twórczość Zbigniewa Uniłowskiego w świetle międzywojennej krytyki literackiej, „Rocznik Naukowo-Dydaktyczny. Wyższa Szkoła Pedagogiczna w Krakowie” 1966, Prace Historycznoliterackie III.

Faron B., Z korespondencji Z. Uniłowskiego, „Miesięcznik Literacki” 1968, z. 2.

Faron B., Zbigniew Uniłowski, Warszawa 1969.

Frankowski P., Emigracja polska w Brazylii w reportażu dwudziestolecia międzywojennego, [w:] Reportaż w dwudziestoleciu międzywojennym, pod red. K. Stępnika i M. Piechoty, Lublin 2004.

Furmanik S., Żyto w dżungli, „Gazeta Polska” 1936, nr 341.

Gombrowicz W., Uniłowski zaplątany w ludzi, [w:] idem, Proza (fragmenty), Reportaże, krytyka literacka: 1933-1939. Dzieła tom XII, pod red. J. Błońskiego, J. Jarzębskiego, wybór i układ J. Jarzębski, Kraków 1995.

Gombrowicz W., Diariusz Rio Parana, [w:] idem, Dziennik 1953-1956, red. J. Błoński, Kraków 1986.

Górski K., Literatura podróżnicza, „Rocznik Literacki”1936.

Groniowski K., Polska emigracja zarobkowa w Brazylii 1871-1914, Wrocław 1972.

Grydzewski M., O „Dzień rekruta”, „Wiadomości Literackie” 1934, nr 49.

Janowska H., Emigracja zarobkowa z Polski 1918-1939, Warszawa 1981.

Jesionowski A., Kilka nowości podróżniczych, „Prosto z Mostu” 1937, nr 14.

Katz J., Młody, gniewny Uniłowski, „Twórczość” 1963, nr 8.

Kołodziej E., Wychodźstwo zarobkowe z Polski 1918-1939, Warszawa 1982.

Król J. A., Przemiany reportażu podróżniczego, „Orka na Ugorze” 1936, nr 28.

Kucharski Z., Chybiona książka o Paranie, ,Tygodnik Ilustrowany” 1937, nr 2.

Szczygieł M, Tochman W., Reportaż prasowy, [w:] Biblia dziennikarstwa, pod red. A. Skworza i A. Niziołka, Kraków 2010.

(m.g.) [M. Grydzewski], Jeszcze „Dzień rekruta”, „Wiadomości Literackie” 1934, nr 50.

Markowski M. P., Potworna powszedniość, [w:] idem, Czarny nurt. Gombrowicz, świat, literatura, Kraków 2004.

Maziarski J., Reportaż, [w:] Stownik rodzajów i gatunków literackich, pod red. G. Gazdy i S. Tynieckiej-Makowskiej, Kraków 2006.

Mazurek J., Kraj a emigracja. Ruch ludowy wobec wychodźstwa polskiego do krajów Ameryki Łacińskiej (do 1939 roku), Warszawa 2006.

Melcer W., Nuda i żyto, „Wiadomości Literackie” 1937, nr 50.

Mikołajczuk A., Punkt(y) widzenia w reportażu. Od etymologii nazwy do tworzywa gatunku, [w:] Punkt widzenia $w$ tekście $i w$ dyskursie, pod red. J. Bartmińskiego, S. Niebrzegowskiej-Bartmińskiej, R. Nycza, Lublin 2004. 
Mikołajczuk A., Pragmatyczno-stylistyczne perspektywy analizy reportażu, „Poradnik Językowy” 2009, $\mathrm{nr} 10$.

Mikułowski A., Cuduś w dżungli, „Myśl Narodowa” 1936, nr 50.

Mortkowicz-Olczakowa H., Zbigniew Uniłowski (portrety $i$ wspomnienia), „Życie Literackie” 1958, nr 4.

Niedzielski C., O teoretycznoliterakich tradycjach prozy dokumentalnej, Torun 1966.

Nowacka B., Reportaże podróżnicze Z. Uniłowskiego - dylematy i paradoksy, [w:] Reportaż w dwudziestoleciu międzywojennym, pod red. K. Stępnika i M. Piechoty, Lublin 2004.

Ossowski J., Uniłoszczak w Kwadrydze, „Poezja” 1979, nr 1.

Pawłowski J., Gombrowicz i lęk. Uwagi o „Diariuszu Rio Parana”, „Pamiętnik Literacki” 1977, z. 4.

Piechal M., Żyto w dżungli, „Pion” 1936, nr 50.

Piechota M., Jaka Ameryka? Polscy reportażyści dwudziestolecia międzywojennego o Stanach Zjednoczonych, Lublin 2002.

Pieszczachowicz J., Niewolnicy pozorów (o Zbigniewie Uniłowskim w 25. rocznicę śmierci), „Tygodnik Powszechny" 1962, nr 47.

Plewko J., Sprostać migracji. Pomoc migrantom ekonomicznym z ziem polskich (połowa XIX-początek XXI wieku), Lublin 2010.

Płachecki M., Klucz do Uniłowskiego, „Tygodnik Kulturalny” 1972, nr 43.

Rejter A., Ksztaltowanie się gatunku reportażu podróżniczego w perspektywie stylistycznej i pragmatycznej, Katowice 2000.

Rogoż S., Żyto w dżungli, „Wiadomości Literackie” 1937, nr 43.

Szczygieł M., Szczegół doprowadzony do manii, [w:] Antologia polskiego reportażu XX wieku, t. 1 1901-1965, pod red. idem, Wołowiec 2014.

Szymański W. P., Legenda o Uniłowszczaku, [w:] idem, Ballady przed burza. Szkice literackie, Warszawa 1961.

„Wiadomości Literackie” 1937, nr 50 (numer w całości poświęcony spuściźnie Zbigniewa Uniłowskiego).

Witosz B., Gatunki podróżnicze w typologicznym ujęciu genologii lingwistycznej, [w:] Wokót reportażu podróżniczego, t. 2, pod red. D. Rotta, Katowice 2007.

Wojtak M., Gatunki dziennikarskie, Lublin 2004.

Wyka K., Literatura podróżnicza, „Rocznik Literacki” 1935.

Wyka K., Tragiczność, drwina i realizm, [w:] idem, Pogranicze powieści, Warszawa 1974.

Ziątek Z., Proza - literatura doświadczeń społeczno-kulturowych, [w:] Literatura polska 1918-1975, t. 2, pod red. A. Brodzkiej, Warszawa 1993.

\section{STRESZCZENIE}

Tematem niniejszego artykułu jest Żyto $w$ dżungli - reportaż Zbigniewa Uniłowskiego. Po przedstawieniu reakcji krytyki oraz kontekstu literacko-społeczego powstania reportażu dokonywana jest interpretacja tekstu. Uniłowski, poprzez manifestacyjne przedstawienie nudy podróży, przeciwstawia się konwencji egzotycznego podróżopisarstwa, co więcej, wielokrotnie prezentuje subiektywizm i niepewność swojego poznania reporterskiego, podejmując dyskusję z obiektywną narracją faktograficzną.

Słowa kluczowe: reportaż, reportaż podróżniczy, dwudziestolecie międzywojenne, Zbigniew Uniłowski, Żyto $w$ dżungli, dekonstrukcja 


\section{SUMMARY}

The theme of this article is The Rye in the Jungle - reportage of Zbigniew Uniłowski. After presenting some reactions from critics, and literary and social context of the creation of the reportage, I made the interpretation of the text. Uniłowski, by the ostentatious presentation of the boredom of travel, opposes the convention of the exotic, travel reportage. Moreover, he very often presents the subjectivity and uncertainty of his knowledge. As a results, he takes a discussion with the nonfiction narrative.

Key words: reportage, travel reportage, Polish interwar period, Zbigniew Uniłowski, The Rye in the Jungle, deconstruction 
